\title{
Correction to: An exploration of sacral morphology using geometric morphometrics and three-dimensionally derived interlandmark distances
}

Tamara Lottering $^{1}$ - Jason Hemingway ${ }^{1} \cdot$ Candice Small $^{1}$

Published online: 8 February 2022

(c) The Author(s), under exclusive licence to Springer-Verlag GmbH Germany, part of Springer Nature 2022

Correction to: International Journal of Legal Medicine (2022)

https://doi.org/10.1007/s00414-021-02724-7

The original article contains an error. Figures 8 and 9 should be removed from the article. Thus, figure 10 will become figure 8 .

The original article has been corrected.

Publisher's note Springer Nature remains neutral with regard to jurisdictional claims in published maps and institutional affiliations.

The online version of the original article can be found at https:// doi.org/10.1007/s00414-021-02724-7

Tamara Lottering

tamaralottering1@gmail.com

$\triangle$ Candice Small

Candice.small@wits.ac.za

1 Human Variation and Identification Research Unit (HVIRU),

School of Anatomical Sciences, Faculty of Health Sciences,

University of the Witwatersrand, Johannesburg 2193,

Republic of South Africa 